5 - ORIGINAL ARTICLE

ISCHEMIA-REPERFUSION

\title{
The influence of low-level laser irradiation on spinal cord injuries following ischemia- reperfusion in rats ${ }^{1}$
}

\author{
Amir Sotoudeh', Amirali Jahanshahi' ${ }^{\mathrm{II}}$, Saeed Zareiy ${ }^{\mathrm{III}}$, Mohammad Darvishi' ${ }^{\mathrm{IV}}$, Nasim Roodbari ${ }^{\mathrm{V}}$, Ali Bazzazan ${ }^{\mathrm{VI}}$ \\ DOI: http://dx.doi.org/10.1590/S0102-865020150090000005

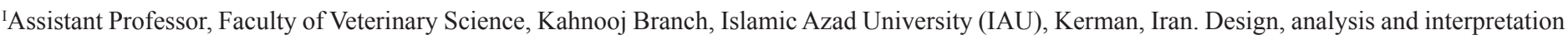 \\ of data; manuscript writing. \\ "Researcher, Elite Club, Kahnooj Branch, IAU, Kerman, Iran. Design and acquisition of data. \\ IIIResident, Aerospace and Subaquatic Medicine School, AJA University of Medical Sciences, Tehran, Iran Branch, and Islamic Azad University, \\ Tehran, Iran. Technical procedures, acquisition and interpretation of data.

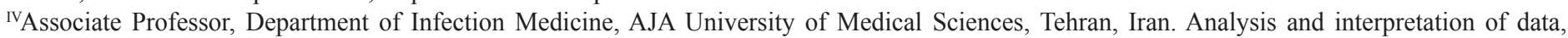 \\ statistical analysis. \\ vAssistant Professor, Faculty of Experimental Science, Kahnooj Branch, Islamic Azad University, Kerman, Iran. Analysis of data, manuscript writing. \\ ${ }^{\mathrm{VI}}$ Graduate student, Faculty of Veterinary Science, Garmsar Branch, IAU, Semnan, Iran. Acquisition and interpretation of data.
}

\section{ABSTRACT}

PURPOSE: To investigate if low level laser therapy (LLLT) can decrease spinal cord injuries after temporary induced spinal cord ischemia-reperfusion in rats because of its anti-inflammatory effects.

METHODS: Forty eight rats were randomized into two study groups of 24 rats each. In group I, ischemic-reperfusion (I-R) injury was induced without any treatment. Group II, was irradiated four times about 20 minutes for the following three days. The lesion site directly was irradiated transcutaneously to the spinal direction with $810 \mathrm{~nm}$ diode laser with output power of $150 \mathrm{~mW}$. Functional recovery, immunohistochemical and histopathological changes were assessed.

RESULTS: The average functional recovery scores of group II were significantly higher than that the score of group I ( $2.86 \pm 0.68$, vs $1.38 \pm 0.09 ; \mathrm{p}<0.05)$. Histopathologic evaluations in group II were showed a mild changes in compare with group I, that suggested this group survived from I-R consequences. Moreover, as seen from TUNEL results, LLLT also protected neurons from I-R-induced apoptosis in rats.

CONCLUSION: Low level laser therapy was be able to minimize the damage to the rat spinal cord of reperfusion-induced injury. Key words: Laser Therapy, Low-Level. Ischemic, Reperfusion. Spinal Cord. Rats. 


\section{Introduction}

Neurologic injuries due to I-R of the spinal cord has an incidence of between $2.9 \%$ and $23 \%{ }^{1}$. Pathogenic mechanisms of neuronal cell death after spinal cord I-R injury include energy failure, excitotoxicity, and oxidative stress ${ }^{2,3}$.There are some applications which can reduce spinal cord I-R injuries such as hypothermia, vascular shunting, left heart bypass, drainage of cerebrospinal fluid, monitoring of somatosensory evoked potentials, single clamp technique and reimplantation of major intercostal arteries ${ }^{4-6}$. Also, there are experimental studies like ischemic preconditioning and adjunctive medications for reducing the incidence of this complication ${ }^{7}$. Despite several surgical modifications and pharmacologic approaches, postoperative spinal cord dysfunction has not been totally eliminated ${ }^{8}$.

Low level laser therapy (LLLT) has photochemical reactions with cell membranes, cellular organelles and enzymes. LLLT can induce a complex chain of physiological reactions by increasing mitochondrial respiration, activating transcription factors, reducing key inflammatory mediators, inhibiting apoptosis, stimulating angiogenesis, and increasing neurogenesis to enhance wound healing, tissue regeneration and reduce acute inflammation ${ }^{9,10}$. LLLT has been clinically applied to treatment of rheumatoid arthritis, periodontal disease, pain management and healing of wounds and burns ${ }^{11-13}$. Many studies approved that LLLT has the potential to be an effective noninvasive therapy for spinal cord injury ${ }^{14,15}$.

The aim of this study is to evaluate if LLLT can protect rats spinal cord from I-R injury, so we hypothesized that LLLT would attenuate immunohistochemical and histopathological changes and improve functional recovery after the ischemia/ reperfusion-induced spinal cord injury in rats.

\section{Methods}

Animal care and experiments were carried out in accordance with the National Institutes of Health Guide for the Care and Use of Laboratory Animals (NIH publications No. 8023). Forty eight male Wistar rats weighing 400-450g were used in this study. Anesthesia was induced by intramuscular injection of ketamine hydrochloride $60 \mathrm{mg} / \mathrm{kg}$ and xylazine $10 \mathrm{mg} / \mathrm{kg}$. A longitudinal incision was made through the skin on the abdominal region and the abdominal aorta was exposed through midline laparotomy. Heparin (250 UI/kg) was administered intravenously before aortic clamping. Spinal cord ischemia was induced by crossclamping for $60 \mathrm{~min}$, using Bulldog forceps (Figure 1).
Vascular clamps were placed under the left renal vein and above the bifurcation in the aorta. Then the forceps were removed and the chest closed routinely. Animals were placed in their cages after recovery. Rats were randomly assigned to two groups.

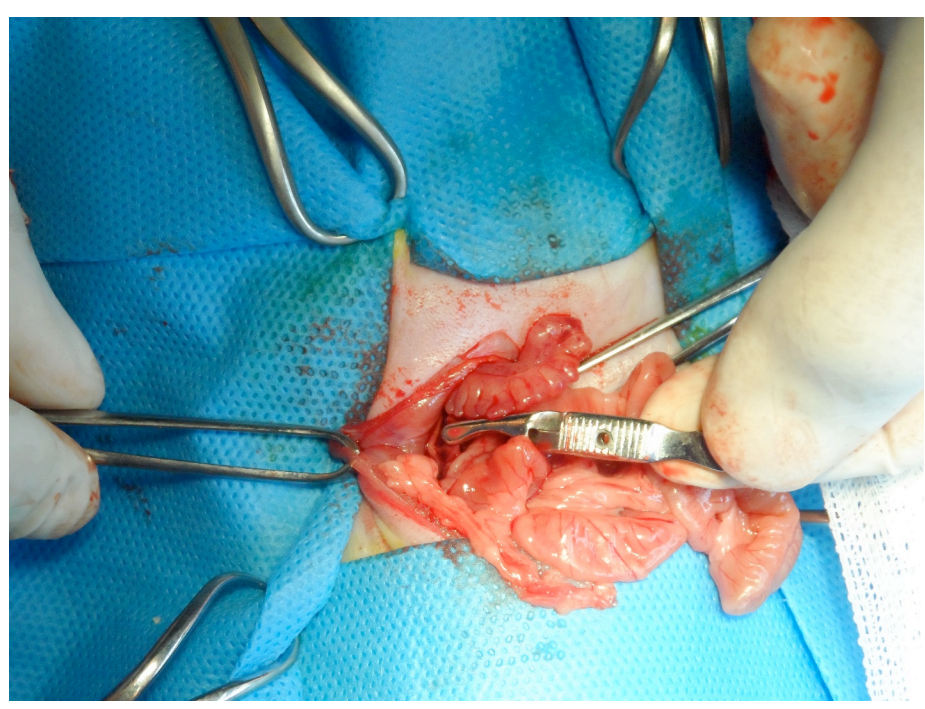

FIGURE 1 - Surgical site: the ventral aorta was exposed and clamped by Bulldog forceps for 60 minutes.

In control group (group I), I-R injury was induced but not irradiated with the laser beam. The irradiation protocol was applied as Byrnes described previously ${ }^{16}$. Briefly in treatment group (group II), 15 minutes after I-R induction on the spinal cord, the lesion site as a rectangular, about $3 \mathrm{~cm}^{2}(3 \mathrm{~cm}$ length $\times 1 \mathrm{~cm}$ width) was irradiated transcutaneously to the spinal direction with $810 \mathrm{~nm}$ diode laser (Thor International, UK;) with output power of $150 \mathrm{~mW}$. The dosage applied to the surface of the skin was 1,589 $\mathrm{J} / \mathrm{cm} 2$ per day $(0.53 \mathrm{~W} / \mathrm{cm} 2,450 \mathrm{~J})$. Irradiation was repeated daily for the following 3 consecutive days. In each day, irradiation was applied 4 times about 20 minutes with contact mode.

\section{Neurologic scoring system}

The Neurologic deficits of animals were evaluated on postoperative 72 hour by a single trained blinded observer by using the following scoring:

Grade 0: paraplegia with no lower extremity motor function;

Grade 1: poor lower extremity motor function;

Grade 2: good movement of the hind limbs, but unable to stand;

Grade 3: able to stand but unable to walk normally;

Grade 4: complete recovery ${ }^{17}$. 


\section{Spinal cord histopathologic examination}

All animals were anesthetized with lethal dose of pentobarbital $(25 \mathrm{mg} / \mathrm{kg})$. Spinal cords were dissected totally and fixed in $10 \%$ formalin and embedded in paraffin with routine procedures. Sections from fourth to sixth lumbar segment were obtained. The spinal cord tissues were embedded in paraffin and serial transverse sections $(5 \mu \mathrm{m})$ cut from paraffin blocks and stained with hemotoxylin and eosin for histopathologic examination. Histopathologic evaluations were performed with means of light microscopy by a neuropathologist who was blinded to experimental conditions.

\section{TUNEL staining}

TUNEL staining was performed by an in situ cell death detection kit (Roche, Germany). Hematoxylin was used to counterstain the sections. Quantitative analysis was performed blindly by counting the number of TUNEL positive neurons in the ventral horns in five microscopic fields as described previously ${ }^{18}$.

\section{Statistical analysis}

All data are expressed as mean \pm standard deviation. Statistical analysis of the neurologic scores were analyzed by using KruskalWallis one-way analysis of variance (ANOVA). The investigators were blinded to the treatments. Values for statistical analyses were considered significant at $\mathrm{p}<0.05$. All analyses were performed by using the SPSS software package (SPSS, Inc, Chicago, Ill).

\section{Results}

Neurological evaluations presented in Table 1. In the group I, the neurological scores was lower. Although in the group II, the Tarlov scale increased and showed a significant difference after $72 \mathrm{~h}$ of reperfusion $(\mathrm{p}<0.05)$.

TABLE 1 - Neurologic status 72 hours after reperfusion as evaluated by the modified Tarlov neurologic recovery scale.

\begin{tabular}{|c|c|c|}
\hline score & $\begin{array}{c}\text { Group I (Control) } \\
\mathbf{N}=\mathbf{2 4} \\
\end{array}$ & $\begin{array}{c}\text { Group II (Treatment) } \\
\mathrm{N}=\mathbf{2 4}\end{array}$ \\
\hline 0 & 8 & 1 \\
\hline 1 & 7 & 3 \\
\hline 2 & 3 & 5 \\
\hline 3 & 4 & 4 \\
\hline 4 & 2 & 11 \\
\hline Mean \pm SD & $1.38 \pm 0.09$ & $2.86 \pm 0.68^{*}$ \\
\hline
\end{tabular}

* Mean neurologic scores showed a significant difference between control and treatment groups $(\mathrm{p}<0.05)$ both at $72 \mathrm{~h}$ after reperfusion.
Histopathologic evaluations in group I, presented that had severe ischemic injury with inclusive necrosis of gray matter, which enclosed typically necrotic nuroglia cells with eosinophilic cytoplasm, and loss of cytoplasmic structures. In addition the numbers of normal nuroglia cells were apparently reduced in this group and neuronal structural alterations were observed, which included oligodendrocytes pyknosis, light staining tigroid body, nucleus's atrophy of nuroglia cell and nucleolus disappearance of oligodendrocytes. Furthermore, hemorrhagic macules were scattered into tissue structures and vacuolar changes were observed in the cytoplasm (Figure 2). The histopathologic changes in group II were milder than that observed in the group I, and the gray matter architecture was generally preserved, with most nuroglia cells appearing to have survived the ischemic consequences (Figure 3).

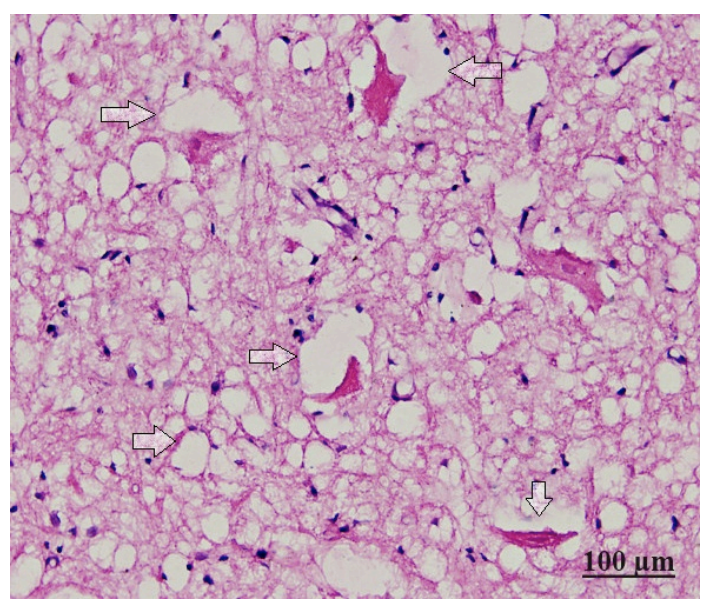

FIGURE 2 - The neurons of spinal cord anterior horn of group I were assessed by $\mathrm{H} \& \mathrm{E}$ staining and viewed at the magnification of 200 times which presented group necrotic changes with prominent vacuolization, intensely eosinophilic cytoplasm, Nissl granule loss, and pyknosis (arrows) as well as by the presence of infiltrating neutrophils and mononuclear phagocytes severe percellular edema and glial cell proliferation.

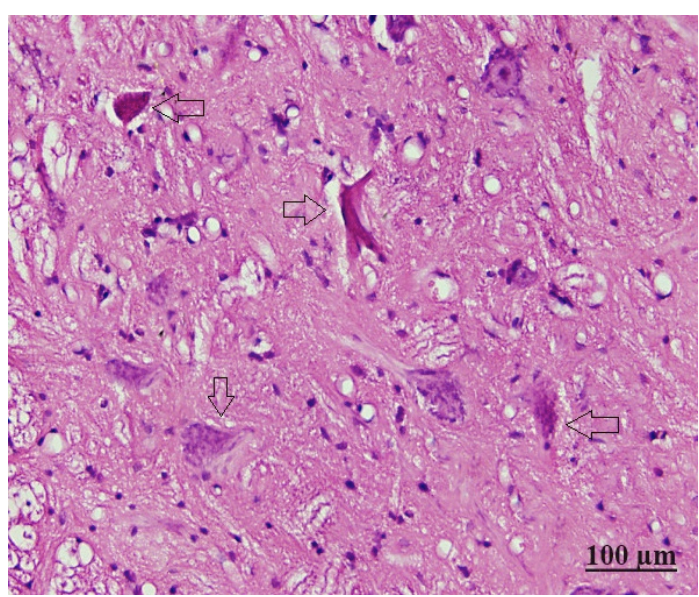

FIGURE 3 - The neurons of spinal cord anterior horn of group II were assessed by H\&E staining and viewed at the magnification of 200 times which showed relative preservation of tissue architecture along with almost complete protection of the neurons, vascular structures, and glial cells along with only mild per cellular edema. The arrows indicate ischemia neuron cells showing mildly eosinophilic cytoplasm, Nissl body loss, and pyknosis. 
Average TUNEL-positive cell counts are shown in Table 2. These data show that the group II exhibited significantly fewer TUNEL-positive cells compared with the group I.

TABLE 2 - Quantitative analysis of the number of TUNEL-positive cells in the ventral horn of spinal cord of all groups, $72 \mathrm{~h}$ after reperfusion.

\begin{tabular}{ccccc}
\hline Group & \multicolumn{2}{c}{ I (Control) } & \multicolumn{2}{c}{ II (Treatment) } \\
\hline $\begin{array}{c}\text { Number of } \\
\text { TUNEL-posetive } \\
\text { motor neurons }\end{array}$ & $\begin{array}{c}\text { Mean } \\
(\mathrm{n}=24)\end{array}$ & SD & $\begin{array}{c}\text { Mean } \\
(\mathrm{n}=24)\end{array}$ & SD \\
\hline
\end{tabular}

* Mean Quantitative analysis showed a significant difference between control and treatment groups $(\mathrm{p}<0.05)$ both at $72 \mathrm{~h}$ after reperfusion.

It is understandable that the number of TUNEL-positive neurons decreased significantly after laser therapy, suggesting that LLLT may protect spinal cords from I-R apoptosis. Spinal cord sections were stained with TUNEL and observed at the light microscopic level (400 times magnification). In the spinal cord ventral horn of the group I, amount of vacuoles appeared and numerous TUNEL-positive neurons were observed (Figure 4). By contrary, very few positively stained neurons were observed in group II (Figure 5).

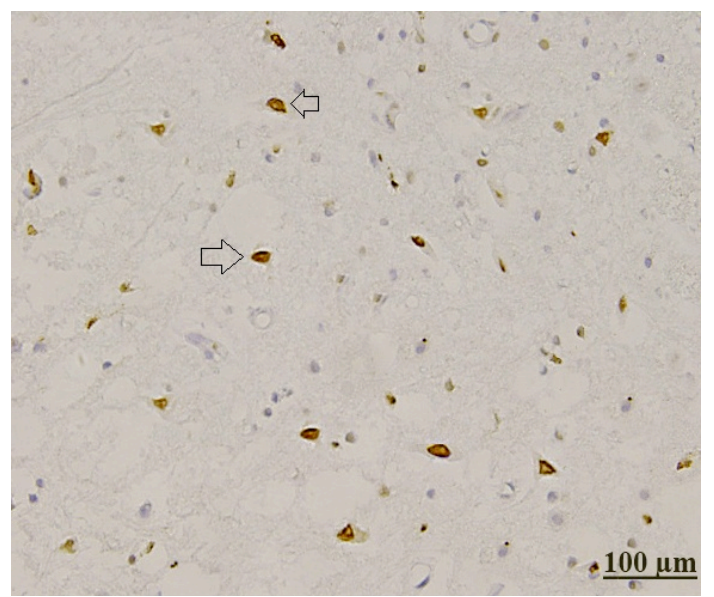

FIGURE 4 - TUNEL staining and quantification of apoptotic motor neurons after reperfusion $(\times 400)$. Many TUNEL-positive neurons with intense nucleus staining were visible in group I. The arrows indicate TUNEL-positive motor neurons.

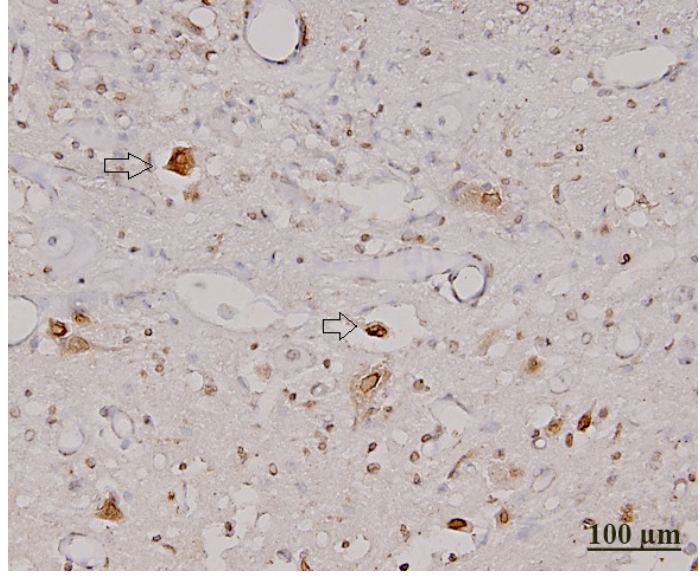

FIGURE 5 - TUNEL staining and quantification of apoptotic motor neurons after reperfusion $(\times 400)$. Only a small number of positively stained neurons were observed in the group II. The arrows TUNELpositive motor neurons.

\section{Discussion}

Our results showed that LLLT will be able to reduce the damages of spinal cord after I-R in rats. This result was verified by both neurological and histological and observations. Additionally, Functional recovery of LLLT group was significantly improved when compared with control group.

Spinal cord I-R injury is a persistent clinical problem in surgical repair of thoracic and thoracoabdominal aneurism surgeries ${ }^{19,20}$. The major cause of spinal cord injury, during and after aortic surgery to the occurrence of one or more of the three following events: (I) the duration and degree of ischaemia; (II) failure to re-establish blood flow to the spinal cord after repair; (III) a biochemically mediated reperfusion injury ${ }^{21}$. Reperfusion is the restoration of blood flow to the organ after a period of ischaemia. Reperfusion of ischaemic neuronal tissues leads to release production of oxygen derived free radicals, produced as a result of incomplete oxygenation during the period of ischaemia ${ }^{22}$. Inflammatory response with production of cytokines by microglia and activated neutrophils also contributes to generation of these radicals ${ }^{23,24}$. Several different surgical strategies and laboratory studies have been developed in attempt to decrease the risk of this devastating complication $^{25-27}$. However, neurological injury in thoracoabdomial surgery remains one of the greatest unsolved mysteries ${ }^{28-30}$.

The therapeutic effects of LLLT have been reported, being associated with production of anti-apoptotic, pro-proliferative, antioxidant, and angiogenic factors ${ }^{31-33}$. LLLT also known as photobiomodulation, is an emerging therapeutic approach in which cells or tissues are exposed to low-levels of red and near-IR light. Its experimental applications have broadened to include serious 
diseases such as heart attack, stroke, and spinal cord injury. Oron et al, suggested that a transcranial application of LLLT after traumatic brain injury provides a significant long-term functional neurological benefit and decreases brain tissue $\operatorname{loss}^{34}$. In another research applied LLLT in acute Spinal cord injury caused by of trauma which promotes axonal regeneration and functional recovery ${ }^{35}$.

LLLT may have beneficial effects in the acute treatment of I-R by reducing inflammatory mediators, inhibiting apoptosis, stimulating angiogenesis, and increasing neurogenesis ${ }^{9}$. Transcranial LLLT applied after ischemic stroke in rats caused a significant improvement of neurological score compared to sham animals ${ }^{36}$.

We hypothesized that LLLT would effectively protect spinal cord by its antioxidant and anti-inflammatory. To our knowledge, the present study probably is the first study to evaluating the neuroprotective effects of LLLT in attenuating I-R induced neurologic injury to the rat spinal cord. It is known that functional recovery after $\mathrm{I}-\mathrm{R}$ is highly correlated with the volume of remaining normal nerve fibers in spinal tissue ${ }^{37}$. Adno et al. ${ }^{11}$, demonstrated transcutaneous application of 810-nm nonpolarized laser significantly promoted axonal regrowth, our results are in agreement with that and show association of improved neurologic status.

Byrnes et $a l .{ }^{16}$, found that $810 \mathrm{~nm}$ light, at a dosage of $1.589 \mathrm{~J} / \mathrm{cm}^{2}$, significantly improves axonal regrowth, functional improvement and statistically significant suppression of immune cell invasion and pro-inflammatory cytokine and chemokine gene expression. Similarly we documented that LLLT had efficient protection on neural cells from apoptosis or necrosis. Also decreased inflammatory cell accumulation in the spinal cords of animals that received LLLT as compared with the control group also supports LLLT proposed anti-inflammatory property and may contribute to neuroprotection.

\section{Conclusion}

Low level laser therapy protects the spinal cord from ischemia-reperfusion injury spinal cord ischemia and provide better locomotor function in rats which may be related to antiinflammatory properties of that.

\section{References}

1. Cambria RP, Davison JK, Zannetti S, L'Italien G, Brewster DC, Gertler JP, Moncure AC, LaMuraglia GM, Abbott WM. Clinical experience with epidural cooling for spinal cord protection during thoracic and thoracoabdominal aneurysm repair. J VascSurg. 1997;25:234-41. PMID: 9052558.

2. Choi DW. Glutamate neurotoxicity and diseases of the nervous system. Neuron. 1998;1:623-34. PMID: 2908446.
3. Dawson TM, Dawson VL, Synder SH. A novel messenger in brain: the free radical, nitric oxide. Ann Neurol. 1992;32:297-311. PMID: 1384420

4. Akgun S, Tekeli A, Kurtkaya O, Civelek A, Isbir SC, Ak K, Arsan S, Sav A. Neuroprotective effects of FK-506, L-carnitine and azathioprine on spinal cord ischemia-reperfusion injury. Eur J Cardiothorac Surg. 2004;25:105-10. PMID: 14690740.

5. Okita Y, Takamoto S, Ando M, Morota T, Yamaki F, Matsukawa $\mathrm{R}$, Kawashima Y. Repair of aneurysms of the entire descending thoracic aorta or thoracoabdominal aorta using a deep hypothermia. Eur J Cardiothorac Surg. 1997;12:120-6. PMID: 9262092.

6. Cambria RP, Giglia JS. Prevention of spinal cord ischemic complications after thoracoabdominal aortic surgery. Eur J Vasc Endovasc Surg. 1998;15:96-109. PMID: 9551047.

7. Isbir CS, Ak K, Kurtkaya O, Zeybek U, Akgun S, Scheitauer BW, Sav A, Cobanoglu A. Ischemic preconditioning and nicotinamide in spinalcord protection in an experimental model of transient aortic occlusion. Eur J Cardiothorac Surg. 2003;23:1028-33. PMID: 12829083.

8. Kiziltepe U, Turan NND, Han U, Ulus AT, Akar F. Resveratrol, a red wine polyphenol, protects spinal cord from ischemia-reperfusion injury. J Vasc Surg. 2004;40(1):138-45. PMID: 15218474.

9. Hashmi JT, Huang YY, Osmani BZ, Sharma SK, Naeser MA, Hamblin MR. Role of low-level laser therapy in neurorehabilitation. PM R. 2010 Dec;2(12 Suppl 2):S292-305. doi: 10.1016/j. pmrj.2010.10.013.

10. Hamblin $\mathrm{M}$, Huang $\mathrm{YY}, \mathrm{Wu} \mathrm{Q}$, Xuan $\mathrm{W}$, Ando $\mathrm{T}, \mathrm{Xu} \mathrm{T}$, Sharma S, Kharkwal G. Low-level light therapy aids traumatic brain injury. Biomed Opt Med Imaging. 2011;10:1-3. doi: 10.1117/2.1201102.003573.

11. Ando T, Sato S, Kobayashi H, Nawashiro H, Ashida H, Hamblin MR, Obara M. Low-level laser therapy for spinal cord injury in rats: effects of polarization. J Biomed Opt. 2013;18(9):1-6. PMID: 24030687.

12. Ekim A, Armagan O, Tascioglu F, Oner C, Colak M. Effect of low level laser therapy in rheumatoid arthritis patients with carpal tunnel syndrome. Swiss Med Wkly. 2007;137(23-24):347-52. PMID: 17629805.

13. Simunovic Z, Ivanovich AD, Depolo A. Wound healing of animal and human body sport and traffic accident injuries using low-level laser therapy treatment: a randomized clinical study of seventy-four patients with control group. J Clin Laser Med Surg. 2000;18(2):6773. PMID: 11800105.

14. Rochkind S, Shahar A, Amon M, Nevo Z. Transplantation of embryonal spinal cord nerve cells cultured on biodegradable microcarriers followed by low power laser irradiation for the treatment of traumatic paraplegia in rats. Neurol Res. 2002;24(4):355-60. PMID: 12069281.

15. Rochkind S. Photoengineering of neural tissue repair processes in peripheral nerves and the spinal cord: research development with clinical applications. Photomed Laser Surg. 2006;24(2):151-7. PMID: 16706693.

16. Byrnes KR, Waynant RW, Ilev IK, Wu X, Barna L, Smith K, Heckert $\mathrm{R}$, Gerst H, Anders JJ. Light promotes regeneration and functional recovery and alters the immune response after spinal cord injury. Lasers Surg Med. 2005;36:171-85. PMID: 15704098.

17. Tarlov IM, Klinger H. Spinal cord compression studies. II. Time limits for recovery after acute compression in dogs. AMA Arch Neurol Psychiatry. 1954 Mar;71(3):271-90. PMID: 13123590.

18. Shan LQ, Ma S, QiuXC, Zhou Y, Zhang Y, ZhengLH, RenPC, Wang YC, Fan QY, MaBA. Hydroxysafflor Yellow A protects spinal cords from ischemia/reperfusion injury in rabbits. Neuroscience. 2010;11:98. doi: 10.1186/1471-2202-11-98. 
19. Liang CL, Lu K, Liliang PC, Chen TB, Chan SHH, Chen HJ. Ischemic preconditioning ameliorates spinal cord ischemiareperfusion injury by triggering autoregulation. J Vasc Surg. 2012 Apr;55(4):1116-23. doi: 10.1016/j.jvs.2011.09.096.

20. Ilhan A, Koltuksuz U, Ozen S, Uz E, Ciralik H, Akyol O. The effects of caffeic acid phenethyl ester (CAPE) on spinal cordischemia/ reperfusion injury in rabbits. Eur J Cardiothorac Surg. 1999;16:45863. PMID: 10571095.

21. Svensson LG. New and future approaches for spinal cord protection. Semin Thorac Cardiovasc Surg. 1997;9(3):206-21. PMID: 9263340

22. Wan IYP, Angelini GD, Bryan AJ, Ryder I, Underwood MJ. Prevention of spinal cord ischaemia during descending thoracic and thoracoabdominal aortic surgery. Eur J Cardiothorac Surg. 2001;19:203-13. PMID: 11167113.

23. Ilhan A, Koltuksuz U, Ozen S, Uz E, Ciralik H, Akyol O. The effects of caffeic acid phenethyl ester (CAPE) on spinal cord ischemia/ reperfusion injury in rabbits. Eur J Cardiothorac Surg. 1999;16:45863. PMID: 10571095.

24. Garcia JH, Liu KF, Yoshida Y, Lian J, Chen S, Del Zoppo G. Influx of leukocytes and platelets in an evolving brain infarct. Am J Pathol. 1994;144:188-99. PMID: 8291608.

25. Etz CD, Luehr M, Kari FA, Bodian CA, Smego D, Plestis KA, Griepp RB. Paraplegia after extensive thoracic and thoracoabdominal aortic aneurysm repair: does critical spinal cord ischemia occur postoperatively? J Thorac Cardiovasc Surg. 2008;135:324-30. doi: 10.1016/j.jtcvs.2007.11.002.

26. Bisdas T, Redwan A, Wilhelmi M, Haverich A, Hagl C, Teebken $\mathrm{O}$, Pichlmaier M. Less-invasive perfusion techniques may improve outcome in thoracoabdominal aortic surgery. J Thorac Cardiovasc Surg. 2010;(21)140:1319-24. doi: 10.1016/j.jtcvs.2010.01.012.

27. Matsuda H, Ogino H, Fukuda T, Iritani O, Sato S, Iba Y, Tanaka H, Sasaki H, Minatoya K, Kobayashi J, Yagihara T. Multi disciplinary approach to prevent spinal cord ischemia after thoracic endovascular aneurysm repair for distal descending aorta. Ann Thorac Surg. 2010;90:561-5. doi: 10.1016/j.athoracsur.2010.04.067.

28. Cunningham JJN, Laschinger JC, Merkin HA, Nathan IM, Colvin S, Ransohoff J, Spencer FC. Measurement of spinal cord ischemia during operations upon the thoracic aorta. Ann Surg. 1982;144:574. doi: 10.1097/00000658-198209000-00007.

29. Laschinger JC, Cunningham JJN, Nathan IM, Knopp EA, Cooper MM, Spencer FC. Experimental and clinical assessment of the adequacy of partial bypass in maintenance of spinal cord blood flow. Ann Thorac Surg. 1983;36:417-26. PMID: 6625737.

30. Cunningham JNJ. Spinal cord ischemia. Introduction. Semin Thorac Cardiovasc Surg. 1998;10:3-5. PMID: 9469770.

31. Huang YY, Chen ACH, Carroll JD, Hamblin MR. Biphasic dose response in low level light therapy. Dose Response. 2009;7(4):35883. doi: 10.2203/dose-response.09-027.Hamblin.

32. Huang YY, Sharma SK, Carroll JD, Hamblin MR. Biphasic dose response in low level light therapy, an update. Dose Response. 2011;9(4):602-18. doi: 10.2203/dose-response.11-009.Hamblin.
33. Xuan W, Vatansever F, Huang L, Wu Q, Xuan Y, Dai T, Ando T, $\mathrm{Xu}$ T, Huang YY, Hamblin MR. Transcranial low-level laser therapy improves neurological performance in traumatic brain injury in mice: effect of treatment repetition regimen. PLoS One. 2013;8(1):e53454. doi: 10.1371/journal.pone.0053454.

34. Oron A, Oron U, Streeter J, de Taboada L, Alexandrovich A, Trembovler V, Shohami E. Low-level laser therapy applied transcranially to mice following traumatic brain injury significantly reduces long-term neurological deficits. J Neurotrauma. 2007;24(4):651-6. PMID: 17439348.

35 Wu X, Dmitriev AE, Cardoso MJ, Viers-Costello AG, Borke RC, Streeter J, Anders JJ. 810nm Wavelength light: an effective therapy for transected or contused rat spinal cord. Lasers Surg Med. 2009 Jan;41(1):36-41. doi: 10.1002/1sm.20729.

36. Detaboada L, Ilic S, Leichliter-Martha S, Oron U, Oron A, Streeter J. Transcranial application of low-energy laser irradiation improves neurological deficits in rats following acute stroke. Lasers Surg Med. 2006 Jan;38(1):70-3. PMID: 16444697.

37. You SW, Chen BY, Liu HL, Lang B, Xia JL, Jiao XY, Ju G. Spontaneous recovery of locomotion induced by remaining fibers after spinal cord transection in adult rats. Restor Neurol Neurosci 2003;21(1-2):39-45. PMID: 12808201.

\section{Correspondence:}

Amir Sotoudeh

Islamic Azad University

Kahnooj Branch

Kahnooj, Iran

Phone: 00989121768066

Fax: 00983495230203

dramirsotoudeh@kahnoojiau.ac.ir

Received: May 6, 2015

Review: July 7, 2015

Accepted: Aug 4, 2015

Conflict of interest: none

Financial source: Islamic Azad University

${ }^{1}$ Research performed at Department of Surgery, Faculty of Veterinary, Islamic Azad University (IAU), Kahnooj Branch. 